\title{
ADHERENCE OF HAEMOPHILUS INFLUENZAE TO HUMAN BUCCAL AND PHARYNGEAL EPITHELIAL CELLS: RELATIONSHIP TO PILATION
}

\author{
M. E. PICHICHERO \\ Department of Pediatrics, University of Rochester \\ School of Medicine and Dentistry, Box 690 \\ Rochester, New York 14642, USA
}

\begin{abstract}
SUmmary. An improved understanding of the role of pili in adherence of Haemophilus influenzae type b to human epithelial cells (EC) would enhance knowledge of the pathogenesis of $H$. influenzae b infections. In this study a highly sensitive in-vitro assay allowed the quantitative assessment of $H$. influenzae $\mathrm{b}$ adherence to EC. The degree of adherence was influenced by incubation time, temperature, bacteria/EC ratio, EC type and the growth phase of the bacteria. Most serially subcultured (SC) capsular type-b strains originally isolated from cerebrospinal fluid, blood, nasopharynx or throat gave similar low degrees of adherence, as did representative single strains of capsular types a, c, d, e and f. SC non-capsulated $H$. influenzae strains adhered in significantly greater numbers than most SC capsulated strains $(\mathrm{p}<0.001)$. One SC type-b strain isolated from a throat, with stable piliation, adhered in very high numbers despite capsulation. Piliated subpopulations selected from type-b capsulated strains adhered in greater numbers than did their parent strains. These data suggest that capsulation of $H$. influenzae is a deterrent to adherence of the bacteria to EC. However, the presence of pili may allow type-b organisms to overcome the effects of capsulation.
\end{abstract}

\section{INTRODUCTION}

The recognition of pili (fimbriae) on Haemophilus influenzae type b has recently been reported from our laboratory (Pichichero et al., 1982) and by Guerina et al. (1982). In several families of gram-negative bacteria, pili have been described as mediating adherence of the organisms to mucosal surfaces and thus initiating pathogenesis (Ofek and Beachey, 1980). In this regard, colonisation of the nasopharynx by $H$. influenzae b in the susceptible host is thought to precede and to be a prerequisite for invasive systemic disease (Moxon et al., 1974). Reports by Lewis and Dajani (1980) and by Lampe et al. (1982) suggest that capsulated $H$. influenzae, including those of type $b$, rarely adhere to human epithelial cells (EC). A study to 
extend our own preliminary observations on pilus-mediated adherence of $H$. influenzae $\mathrm{b}$ to $\mathrm{EC}$ is reported here.

The sensitive assay method described below allowed for the consistent detection of low degrees of adherence to EC achieved by serially subcultured (SC) H. influenzae b. Adherence of clinical isolates of $H$. influenzae $\mathrm{b}$ isolated from cerebrospinal fluid (CSF), blood or mucosal surfaces, including several paired strains from separate sources in the same patient, was quantitatively compared with the adherence achieved by clinical isolates of non-capsulated $H$. influenzae and by selected subpopulations of highly piliated capsulated strains.

\section{MATERIAL AND METHODS}

Bacteria. The adherence assay was developed and standardised with two strains of $H$. influenzae: strain Eag (sometimes referred to later as cap + ) is a type-b capsulated strain which was isolated from CSF, and strain Eagb-S2 (cap-) is a capsule-deficient mutant of strain Eag. Eag capsulation is genetically very stable and since its original description (Anderson, Johnston and Smith, 1972) strain Eag has become a "standard" strain employed in many studies of $H$. influenzae b pathogenesis. Strain Eagb-S2 produces about one-thousandth of the amount of capsular material produced by strain Eag as determined by haemagglutination-inhibition assays of culture supernates or of sonic extracts of cells (Anderson et al., 1972; Weller et al., 1978). It was a spontaneous mutant, appearing as a non-mucoid colony on a pure plate culture of strain Eag. The outer membrane protein compositions of strains Eag and Eagb-S2 are identical (Loeb and Smith, 1980). Other $\boldsymbol{H}$. influenzae strains evaluated were single laboratory stock strains of capsular types a, c, d, e and $\mathrm{f}$ and clinical isolates from the Children's Hospital Medical Center, Boston, MA., or from the Strong Memorial Hospital, Rochester, NY. The stock culture of each bacterial strain was prepared from a second serial subculture after primary isolation on chocolate agar from the patient. The bacteria were suspended in sterile skim milk and frozen at $-70^{\circ} \mathrm{C}$. Fresh cultures were initiated by partly defrosting the stock, streaking a loopful of bacteria on to brain-heart infusion agar supplemented with X and V factors (XV-BHI; Anderson et al., 1972), and incubating overnight at $37^{\circ} \mathrm{C}$.

Determination of capsulation. Capsular types of $H$. influenzae strains were determined by the slide-agglutination technique. One drop of phosphate-buffered saline (PBS) containing c. $10^{9}$ bacteria was mixed on a glass slide with one drop of hyperimmune rabbit or horse serum containing specific anticapsular antibody (induced by repeated injection of whole, formalinkilled, capsulated $H$. influenzae); the mixture was examined for visible agglutination.

A modification of the radio-antigen binding assay described by Anderson (1978) was used to estimate the degree of type-b capsulation. Twenty-five $\mu l$ of ${ }^{3} \mathrm{H}$-labelled purified $H$. influenzae b capsular polysaccharide were mixed with $25 \mu \mathrm{l}$ of the study bacterial strain at various concentrations, and the mixtures were incubated for $60 \mathrm{~min}$. Twenty-five $\mu \mathrm{l}$ of a serum with known anticapsular antibody content were then added and the percentage fall in binding of ${ }^{3} \mathrm{H}$-capsular polysaccharide to antibody caused by the bacteria was compared with the falls caused by known concentrations of non-radioactive purified capsular material. From this comparison it was possible to deduce the amount of capsule per bacterium of the study strain.

Collection of epithelial cells. EC were obtained by scraping the buccal mucosa or posterior oropharynx of a healthy adult laboratory worker (male or female) with a wooden tongue depressor. Unless otherwise stated, the cells from the same four or six subjects (depending on

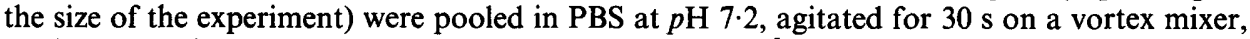
washed three times in PBS, and then resuspended to $2 \times 10^{5} \mathrm{EC} / \mathrm{ml}$ in PBS containing $0.15 \mathrm{mM}$ $\mathrm{CaCl}_{2}, 0.05 \mathrm{mM} \mathrm{MgCl} 2$ and $0.1 \%$ bovine serum albumin (PCMA).

${ }^{3} \mathrm{H}$-labelling of bacteria. After overnight growth on XV-BHI at $37^{\circ} \mathrm{C}$, a loopful of bacterial culture was transferred to a supplemented tryptone and yeast extract broth (basal medium) with glucose $0 \cdot 1 \%$, and grown at $37^{\circ} \mathrm{C}$, with aeration provided by shaking, to a density of $4 \times 10^{8}$ $\mathrm{cfu} / \mathrm{ml}$ (Anderson, 1978). The bacteria were then washed once in basal medium. A 20- $\mu \mathrm{l}$ inoculum of the washed bacteria was added, with $180 \mu \mathrm{l}$ of fresh basal medium, to a $10 \times 75$ glass 
tube containing $100 \mu \mathrm{l}$ of dried $6{ }^{3} \mathrm{H}-\mathrm{D}-$ glucose (New England Nuclear Corp., Boston, MA., $1 \mathrm{mCi} / \mathrm{ml}, 30 \mathrm{Ci} / \mathrm{mmol}$ ), and incubated at $37^{\circ} \mathrm{C}$ with aeration for $2 \mathrm{~h}(\log$ phase) or $16 \mathrm{~h}$ (stationary phase). The bacteria were then sedimented by centrifugation at $8000 \mathrm{~g}$ for $5 \mathrm{~min}$ at $4^{\circ} \mathrm{C}$ (Eppendorf Centrifuge, Model 3200, Brinkman Instruments, Westbury, NY), after which they were washed once in basal medium and resuspended in PCMA to a concentration of $1 \times 10^{8}$ $\mathrm{cfu} / \mathrm{ml}$, as determined by direct visual count with a Petroff-Hausser chamber. This labelling method resulted in a specific activity of $0 \cdot 01-0.3$ counts $/ \mathrm{min} /$ bacterium.

Haemagglutination (HA) assay was performed as previously described (Pichichero et al., 1982). Briefly, bacteria from a fresh culture plate were suspended in PBS at a concentration of $10^{9} / \mathrm{ml}$, then serially diluted in two-fold steps in PBS. To $25 \mu \mathrm{l}$ of bacterial suspension in a well of a microtitration tray were added $25 \mu \mathrm{l}$ of a $1 \% \mathrm{v} / \mathrm{v}$ suspension in PBS of human red blood cells (RBC) that had previously been washed three times in PBS. The tray was left at room temperature for $60 \mathrm{~min}$, and the highest dilution of bacteria giving visible HA was recorded.

Selection of bacteria with greater capacity for adherence. Three $\mathrm{ml}$ of bacterial suspension $\left(10^{9} \mathrm{cfu} / \mathrm{ml}\right)$ were mixed with $3 \mathrm{ml}$ of RBC in PBS $(5 \% \mathrm{v} / \mathrm{v})$ and left at room temperature for 30 min to allow adherence. This mixture was layered over $2 \mathrm{ml}$ of Ficoll-Pacque (Pharmacia, Fairlawn, NJ) and allowed to settle. The RBC pellet was then inoculated on to agar and incubated at $37^{\circ} \mathrm{C}$ overnight.

Electron microscopy. A $10-\mu \mathrm{l}$ droplet of $H$. influenzae b suspended $\left(10^{9} \mathrm{cfu} / \mathrm{ml}\right)$ in $0 \cdot 1 \mathrm{M}$ sodium phosphate buffer $(p \mathrm{H} \mathrm{7)}$ was applied to a Formvar carbon-strengthened grid. Excess fluid was immediately removed, and the specimen was stained with uranyl acetate $(2 \% \mathrm{v} / \mathrm{v})$ for 1 min and observed and photographed by transmission electron microscopy.

Adherence assay with radiolabelled bacteria. EC, 50000 in PCMA buffer $(0.25 \mathrm{ml})$, were added to $2.5 \times 10^{6}{ }^{3} \mathrm{H}$-labelled bacteria $(25 \mu \mathrm{l})$ in $12 \times 75 \mathrm{~mm}$ borosilicate glass tubes (American Scientific Products, Rochester, NY) which had been pre-soaked in PBS with $0 \cdot 2 \%$ Tween 20 (P/Tween; Fisher Scientific Products, Fairlawn, NJ). The tubes were incubated at $37^{\circ} \mathrm{C}$ for 30 min with gentle agitation every $10 \mathrm{~min}$. The EC were washed four times with PBS and pelleted by differential centrifugation to remove non-adherent bacteria $(50 \mathrm{~g}$ for $10 \mathrm{~min}$ in an IEC centrifuge; IEC, Needham Heights, MA). Control tubes containing buffer and ${ }^{3} \mathrm{H}$-bacteria but no EC were processed in the same way and at the same time. The pellets were transferred to 1.5-ml polypropylene conical tubes (Sarstadt Inc., W. Germany), with several $25-\mu$ l rinses of the borosilicate glass tubes to ensure the transfer of the entire pellet. The cells were disrupted by adding $0.4-0.8 \mathrm{ml}$ of Protosol (New England Nuclear), and counted at $8^{\circ} \mathrm{C}$ in $10 \mathrm{ml}$ of scintillant ( $4 \mathrm{~g}$ of 2,5 diphenyloxazole and $0.05 \mathrm{~g}$ of 1,4-bis-2-(5-phenyloxazolyl)-benzene/ $\mathrm{L}$ of toluene). The number of bacteria per EC (b/EC) was calculated by subtracting the ${ }^{3} \mathrm{H}$-label in the control tubes from the ${ }^{3} \mathrm{H}$-label in the experimental tubes. Adherence was expressed as the mean value for $b / E C \pm$ the standard error of the mean. Experiments were performed in duplicate.

Preliminary experiments established that non-specific attachment of bacteria to the reaction vessel occurred, and that this was accompanied by the attachment of ${ }^{3} \mathrm{H}$-labelled capsular polysaccharide released from the bacterial surface of capsulated strains during incubation with EC. To minimise this problem, a variety of reaction vessels, preincubation buffers and suspending buffers were evaluated. The lowest degrees of non-specific attachment occurred with borosilicate glass tubes that had been filled with $\mathrm{P} / \mathrm{Tween}$ for $30 \mathrm{~min}$ at $20^{\circ} \mathrm{C}$, emptied and dried in air and with PCMA as the suspending buffer for incubation. However, even under these conditions, non-specific attachment occurred to some extent, and transfer of the EC pellet to a separate tube for ${ }^{3} \mathrm{H}$ counting was necessary.

Adherence detection by visual inspection. Twenty-five $\mu \mathrm{l}$ of $H$. influenzae $\left(2.5 \times 10^{6} \mathrm{cfu}\right)$ were added to $50000 \mathrm{EC}(0.25 \mathrm{ml})$ in a borosilicate tube (prepared as described above) and incubated at $37^{\circ} \mathrm{C}$ for $30 \mathrm{~min}$ with gentle agitation every $10 \mathrm{~min}$. Non-adherent bacteria were removed by a series of four differential centrifugations $(50 \mathrm{~g}$ for $10 \mathrm{~min})$. The EC pellet was placed on a glass slide, dried in air and stained by Gram's method, and 40-50 cells were examined at $1000 \mathrm{X}$ magnification for adherent gram-negative pleomorphic bacilli. To control for indigenous gram-negative pleomorphic rods adherent to EC, $25 \mu \mathrm{l}$ of PCMA buffer were added to the EC instead of the $H$. influenzae and processed as above. The background number of gram-negative pleomorphic rods was virtually zero.

Low degrees of bacterial adherence could not be reliably counted by this method; however, 
gram-negative pleomorphic rods were seen in all experimental preparations. Only highly EC-adherent bacteria (such as strains C54 and C186), seen as clusters of 10-15 b/EC, could be reproducibly counted. Therefore, this method of quantitating adherence was used only for gross confirmation of the results obtained with the radiolabelled-bacteria method.

Statistical analysis. Comparisons of means were by Student's $t$-test. An analysis of variance was used to determine the sources of variation in the assay system.

\section{RESULTS}

\section{Effect of incubation time, temperature, and $\mathrm{pH}$ on adherence}

Adherence occurred rapidly, was detected $10 \mathrm{~min}$ after the addition of bacteria to $\mathrm{EC}$, and was maximal after incubation for $30 \mathrm{~min}$ (Figure). Adherence by the cap -

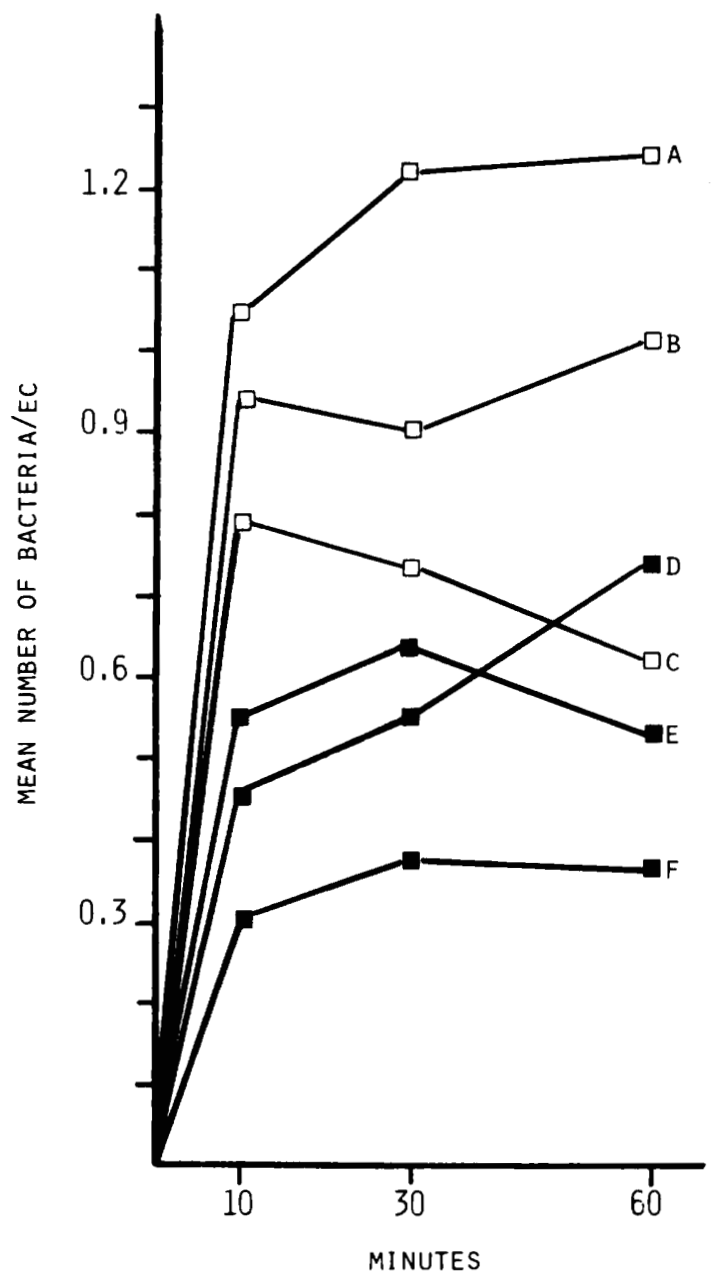

FIG.-Influence of incubation time on adherence of stationary-phase bacteria to buccal epithelial cells at $37^{\circ} \mathrm{C}$. Representative experiments on three days (A and $\mathrm{D}$, day $1 ; \mathrm{B}$ and $\mathrm{E}$, day 2 ; $\mathrm{C}$ and $\mathrm{F}$, day 3 ). Strain Eagb-S2 (cap-) $\square-\square$, strain Eag (cap+) 
strain was greater than that by the cap + strain after each time interval in each of the three experiments. Temperature also influenced adherence. Stationary-phase cap + organisms adhered in greater numbers after incubation for $30 \mathrm{~min}$ at $37^{\circ} \mathrm{C}(\mathrm{b} / \mathrm{EC}$ $0.7 \pm 0.1)$ than at $22^{\circ} \mathrm{C}(\mathrm{b} / \mathrm{EC} 0.6 \pm 1 \cdot 1)$ or at $4^{\circ} \mathrm{C}(\mathrm{b} / \mathrm{EC} 0.4 \pm 0.2)$; there was a significant difference between adherence at $37^{\circ} \mathrm{C}$ and at $4^{\circ} \mathrm{C}(\mathrm{p}<0.05)$. Similar results were obtained with the cap - strain. The $p \mathrm{H}$ of the suspending buffer had no effect on adherence over a $p \mathrm{H}$ range of 6-8. Therefore, in all subsequent experiments incubation was for $30 \mathrm{~min}$ at $37^{\circ} \mathrm{C}$ and at $p \mathrm{H} 7 \cdot 2$.

\section{Effect of $H$. influenzae growth phase on adherence}

Cap - adherence to EC was significantly less when bacteria were in the log phase (b/EC $0.4 \pm 0.1$ ) than when they were in the stationary phase (b//EC $1.2 \pm 0.2$; $p<0.001)$. The same was found with the cap + strain-log-phase $b / E C 0 \cdot 1 \pm 0.02$; stationary phase $\mathrm{b} / \mathrm{EC} 0.6 \pm 0 \cdot 1 ; \mathrm{p}<0.02$.

\section{Effect of bacteria: EC ratio on adherence}

The number of $H$. influenzae adhering to EC varied directly with the number of bacteria added. In keeping with the findings of Svanborg-Eden, Eriksson and Hanson (1977) and Andersson et al. (1981), optimal adherence occurred at b/EC ratios of $10^{3}-10^{4}: 1$. However, in the assay system reported here, ratios in excess of $100: 1$ resulted in high background counts of ${ }^{3} \mathrm{H}$-label complicating the reliable interpretation of results. A ratio of 100-50:1 allowed quantifiable determination of adherence while minimising this problem.

\section{Effect of EC source on adherence}

Adherence of the cap + strain to oropharyngeal cells $(\mathrm{b} / \mathrm{EC} 0.9 \pm 0 \cdot 2)$ was identical with that observed with buccal cells $(\mathrm{b} / \mathrm{EC} 0 \cdot 9 \pm 0 \cdot 2)$. However, pharyngeal cells have smaller surface areas than buccal cells. Bacteria/pharyngeal cell counts need to be multiplied by a correction factor of 3.74 to make them comparable to bacteria/buccal cell counts (Salit and Morton, 1981). Therefore, on the basis of epithelial cell surface area available for bacterial binding, the adherence to pharyngeal cells was 3.74 times greater.

\section{Effects of different EC donors and of day-to-day donor variations on adherence}

EC from the six individuals who regularly provided cells were compared as recipients of adherent bacteria. Variability between donors was found (table I). An analysis of variance of these data showed that $64 \%$ of the variation in the assay was attributable to differences in the strains, $9 \%$ to variation between donors, $5 \%$ to day-to-day variation, and $22 \%$ to interactions between these three variables. (Note, however, the lack of overlap of $\mathrm{b} / \mathrm{EC}$ ranges for the cap + and the cap - strains.) Pooling of donor EC from four or six of these subjects to form a "standard" lot of cells limited the influence of donor-to-donor variation. Day-to-day variation in the pooled cells was not significant $(0.09 \pm 0.02$ versus $0.11 \pm 0.02$ for the cap + strain; $0.31 \pm 0.03$ versus $0.43 \pm 0.03$ for the cap - strain); however, to reduce the contribution of 
TABLE I

Representative experiments comparing adherence of strains Eag (cap +) and Eagb-S2 (cap -) on two days with six donors and log-phase bacterial cultures

\begin{tabular}{|c|c|c|c|c|}
\hline \multirow[b]{3}{*}{ Donor no. } & \multicolumn{4}{|c|}{ Bacteria/epithelial cell ratios obtained with strains } \\
\hline & \multicolumn{2}{|c|}{ Eag (Cap+) } & \multicolumn{2}{|c|}{ Eagb-S2 (Cap-) } \\
\hline & Day 1 & Day 2 & Day 1 & Day 2 \\
\hline $\begin{array}{c}1 \\
2 \\
3 \\
4 \\
5 \\
6 \\
\text { Mean } \pm \text { SE }\end{array}$ & $\begin{array}{c}0.02 \\
0.03 \\
0 \cdot 10 \\
0.12 \\
0.14 \\
0 \cdot 10 \\
0.09 \pm 0.02\end{array}$ & $\begin{array}{c}0.11 \\
0.05 \\
0.08 \\
0.09 \\
0.13 \\
0.22 \\
0 \cdot 11 \pm 0.02\end{array}$ & $\begin{array}{c}0.32 \\
0.38 \\
0.18 \\
0.30 \\
0.42 \\
0.26 \\
0.31 \pm 0.03\end{array}$ & $\begin{array}{c}0.48 \\
0.19 \\
0.36 \\
0.54 \\
0.36 \\
0.66 \\
0.43 \pm 0.07\end{array}$ \\
\hline
\end{tabular}

day-to-day donor cell variation and its interactions with other variables, strain Eag was always included in each day's experiment, and adherence of the test strain was compared to that of strain Eag. The figure derived from such a comparison is referred to below as the relative attachment (RA).

\section{Comparative adherence of clinical isolates from different sites}

The adherence of SC strains of $H$. influenzae derived from clinical specimens is recorded in table II. Adherence of 10 type-b strains from CSF was similar to that of strain Eag (RA 1.0 $\pm 0 \cdot 2$ ). The same was true of eight type-b strains from blood (RA $1 \cdot 3 \pm 0 \cdot 3$ ) and of five other capsulated strains (one each of types a, c, d, e and f; RA $1 \cdot 0 \pm 0 \cdot 1)$. Non-capsulated isolates adhered to EC in significantly greater numbers (RA $3.4 \pm 0.6)$ than did these capsulated strains $(p<0.001)$. The mean relative attachment of the type-b isolates for the pharynx was high $(7 \cdot 0 \pm 3 \cdot 7)$, largely because of two exceptionally adherent strains (C54 and C186). Strain C54 was unusual in its ability to maintain stable piliation during serial in-vitro subculture. Since our previous report (Pichichero et al., 1982), strain $\mathrm{Cl} 186$ has been found to be a capsule-deficient type-b organism similar to strain Eagb-S2, possessing one-tenth as much capsular material per organism as a typical type-b strain.

\section{Effects of serial RBC passage on adherence}

Several strains from the CSF, blood, and pharyngeal groups were randomly selected, along with strains C54, C186 and strain Eag, to undergo serial passage on RBCs (see Methods) to obtain more highly EC-adherent bacterial populations (Pichichero et al., 1982). The selection process was performed once with strains C54 and $\mathrm{C} 186$ and at least once with the remaining strains until, in each case, a positive $\mathrm{HA}$ titre of at least 1 was achieved. A clear relationship between an increasing HA titre and enhanced bacterial adherence was observed (table II). RBC-selected derivatives of CSF, blood and pharyngeal strains gave RA values of $5.5 \pm 1.3,4.0 \pm 0.7$ and $23 \cdot 1 \pm 12 \cdot 3$ respectively; these were significantly greater than those for the SC parents $(\mathrm{p}<0.01$, paired $t$ test). Subsequent serial non-selective in-vitro culture of some of 
TABLE II

Relative attachment of $H$. influenzae clinical isolates to human epithelial cells

\begin{tabular}{|c|c|c|c|c|c|c|c|c|c|c|c|}
\hline \multirow{3}{*}{$\begin{array}{l}\text { Source } \\
\text { of } \\
\text { Strain }\end{array}$} & \multirow[b]{3}{*}{$\begin{array}{l}\text { Capsule } \\
\text { type }\end{array}$} & \multirow[b]{3}{*}{ Strain } & \multicolumn{9}{|c|}{ Results obtained with $H$. influenzae strains } \\
\hline & & & \multicolumn{3}{|c|}{$\begin{array}{l}\text { After non-selective } \\
\text { subculture }\end{array}$} & \multicolumn{3}{|c|}{$\begin{array}{l}\text { After serial passage } \\
\text { on } \mathrm{RBC}\end{array}$} & \multicolumn{3}{|c|}{$\begin{array}{l}\text { After return to non-selective } \\
\text { subculture }\end{array}$} \\
\hline & & & $\begin{array}{l}\text { HA } \\
\text { titre }\end{array}$ & $\begin{array}{l}\text { Relative* } \\
\text { attachment }\end{array}$ & $\begin{array}{l}\text { Presence } \\
\text { of pili }\end{array}$ & $\begin{array}{l}\text { HA } \\
\text { titre }\end{array}$ & $\begin{array}{l}\text { Relative* } \\
\text { attachment }\end{array}$ & $\begin{array}{l}\text { Presence } \\
\text { of pili }\end{array}$ & $\begin{array}{l}\text { HA } \\
\text { titre }\end{array}$ & $\begin{array}{l}\text { Relative* } \\
\text { attachment }\end{array}$ & $\begin{array}{l}\text { Presence } \\
\text { of pili }\end{array}$ \\
\hline \multirow{11}{*}{ CSF } & \multirow{11}{*}{ b } & (Eag & $<1$ & $1 \cdot 0$ & - & 16 & $12 \cdot 3$ & + & $<1$ & 1.2 & - \\
\hline & & $R a b$ & $<1$ & 1.0 & - & 16 & $4 \cdot 2$ & + & $<1$ & 0.7 & - \\
\hline & & Mad & $<1$ & 0.9 & $\ldots$ & $\ldots$ & $\ldots$ & $\ldots$ & $\ldots$ & $\ldots$ & $\ldots$ \\
\hline & & $\mathrm{C} 47$ & $<1$ & 0.3 & $\ldots$ & 8 & 5.8 & $\ldots$ & $\ldots$ & $\ldots$ & $\ldots$ \\
\hline & & C154 & $<1$ & 0.8 & $\ldots$ & $\ldots$ & $\ldots$ & $\ldots$ & $\ldots$ & $\ldots$ & $\ldots$ \\
\hline & & H113 & $<1$ & 0.5 & - & 2 & 1.8 & + & $<1$ & 0.7 & - \\
\hline & & H292 & $<1$ & $2 \cdot 1$ & - & 4 & $6 \cdot 4$ & $\ldots$ & $\ldots$ & $\ldots$ & $\ldots$ \\
\hline & & H305 & $<1$ & 1.4 & - & 2 & $2 \cdot 9$ & + & $<1$ & $2 \cdot 1$ & - \\
\hline & & $39-12$ & $<1$ & 1.8 & $\ldots$ & $\ldots$ & $\ldots$ & $\ldots$ & $\ldots$ & $\cdots$ & $\cdots$ \\
\hline & & $39-15$ & $<1$ & $1 \cdot 4$ & $\cdots$ & $\cdots$ & $\ldots$ & $\ldots$ & $\ldots$ & $\ldots$ & $\ldots$ \\
\hline & & S112 & $<1$ & $0 \cdot 1$ & $\cdots$ & 2 & $5 \cdot 1$ & $\cdots$ & $\ldots$ & $\cdots$ & $\cdots$ \\
\hline \multirow{8}{*}{ Blood } & \multirow{8}{*}{ b } & C194 & $<1$ & $1 \cdot 0$ & - & 2 & 3.5 & + & $<1$ & 1.8 & - \\
\hline & & $39-3$ & $<1$ & 2.5 & $\ldots$ & $\ldots$ & $\ldots$ & $\ldots$ & $\ldots$ & $\ldots$ & $\ldots$ \\
\hline & & $39-4$ & $<1$ & $1 \cdot 4$ & $\cdots$ & $\ldots$ & $\ldots$ & $\ldots$ & $\ldots$ & $\ldots$ & $\ldots$ \\
\hline & & $39-13$ & $<1$ & 0.2 & $\ldots$ & $\ldots$ & $\ldots$ & $\ldots$ & $\ldots$ & $\ldots$ & $\ldots$ \\
\hline & & |39-14 & $<1$ & 1.7 & $\ldots$ & $\ldots$ & $\ldots$ & $\ldots$ & $\ldots$ & $\ldots$ & $\ldots$ \\
\hline & & $\$ 109$ & $<1$ & 0.4 & $\ldots$ & 1 & 3.3 & $\ldots$ & $\ldots$ & $\ldots$ & $\ldots$ \\
\hline & & S113 & $<1$ & $2 \cdot 2$ & - & 2 & $6 \cdot 0$ & + & $<1$ & 0.7 & - \\
\hline & & $\mathrm{S} 124$ & $<1$ & $1 \cdot 3$ & $\ldots$ & 1 & $3 \cdot 3$ & $\ldots$ & $\ldots$ & $\cdots$ & $\cdots$ \\
\hline \multirow{7}{*}{$\begin{array}{l}\text { Throat or } \\
\text { naso- } \\
\text { pharynx }\end{array}$} & \multirow{7}{*}{$b$} & (C22 & $<1$ & $2 \cdot 0$ & $\ldots$ & $\ldots$ & $\ldots$ & $\ldots$ & $\ldots$ & $\cdots$ & $\ldots$ \\
\hline & & C24 & $<1$ & $1 \cdot 1$ & $\ldots$ & 1 & 6.7 & $\ldots$ & $\ldots$ & $\ldots$ & $\ldots$ \\
\hline & & C54 & 4 & $25 \cdot 5$ & + & 32 & 57.0 & + & 4 & $16 \cdot 2$ & + \\
\hline & & $\{\mathrm{Cl21}$ & $<1$ & 1.7 & $\ldots$ & 1 & $3 \cdot 3$ & $\ldots$ & $\ldots$ & $\ldots$ & $\ldots$ \\
\hline & & $\mathrm{Cl} 186 \dagger$ & 2 & 15.6 & $(+)$ & 16 & $25 \cdot 5$ & $(+)$ & 2 & $11 \cdot 4$ & $(+)$ \\
\hline & & C196 & $<1$ & 1.8 & $\ldots$ & $\ldots$ & $\ldots$ & $\ldots$ & $\ldots$ & $\ldots$ & $\ldots$ \\
\hline & & $39-5$ & $<1$ & 1.4 & $\ldots$ & $\ldots$ & $\ldots$ & $\ldots$ & $\ldots$ & $\cdots$ & $\ldots$ \\
\hline Sputum & $\begin{array}{l}\text { Non- } \\
\text { capsulated }\end{array}$ & $\mathrm{C} 37$ & $<1$ & $1 \cdot 3$ & & & & & & & \\
\hline Sputum & , & $\mathrm{C} 83$ & $<1$ & 5.0 & & & & & & & \\
\hline Trachea & , & $\mathrm{C} 270$ & $<1$ & $2 \cdot 3$ & & & & & & & \\
\hline Eye & ” & $\mathrm{C} 273$ & $<1$ & 1.6 & & & & & & & \\
\hline Trachea & , & C304 & $<1$ & 3.0 & & & & & & & \\
\hline Nose & ", & C333 & $<1$ & 3.7 & & & & & & & \\
\hline Sputum & ", & C353 & $<1$ & $6 \cdot 1$ & & & & & & & \\
\hline Nose & ", & C379 & $<1$ & 3.8 & & & & & & & \\
\hline & la & & $<1$ & 1.2 & & & & & & & \\
\hline & c & & $<1$ & $1 \cdot 3$ & & & & & & & \\
\hline stock strains & $\{d$ & & $<1$ & 0.8 & & & & & & & \\
\hline & e & & $<1$ & 0.7 & & & & & & & \\
\hline & f & & $<1$ & $1 \cdot 2$ & & & & & & & \\
\hline
\end{tabular}

- Relative to strain Eag-see text.

† Capsule deficient

Strains from different sites in the same patients were: $C 47$ and $C 54 ; 39-12$ and $39-13 ; 39-15$ and $39-14 ; S 112$ and S113; 39-3, 39-4 and 39-5.

these $\mathrm{HA}+$, highly EC-adherent subpopulations resulted in a return of HA capability and EC attachment to parental levels (table II).

Piliation of type-b isolates from different sources

Four type-b strains from CSF, two from blood and the pharyngeal strains C54 and 
C186 were examined by electron microscopy for the presence of pili. Pili were not detected on the six SC parent strains from CSF and blood, all of which adhered in low numbers to EC and failed to agglutinate RBCs (i.e., were $\mathrm{HA} \mathrm{-}$ ) (table II). The SC parent pharyngeal strain $\mathrm{C} 54$ adhered in large numbers to $\mathrm{EC}$, was $\mathrm{HA}+$ and possessed many pili (c. 40/bacterium). The SC parent pharyngeal strain C186 (with deficient type-b capsule) also adhered well to EC and was $\mathrm{HA}+$; however, it had only c. 10 pili/bacterium, and many individual bacteria had no pili.

\section{Effect of serial RBC passage on piliation}

The eight type-b strains described above were among those that underwent serial passage on RBCs. The four strains from CSF and two from blood, when they had become $\mathrm{HA}+$, adhered in greater numbers to EC than did the parent SC strains and in all six cases this increase in adherence was associated with possession of numerous pili (c. 40/bacterium; table II). After RBC passage, the HA titre of strain C54 increased from 4 to 32. Associated with this increase in HA titre was an increase in RA. However, because strain C54 was heavily piliated directly from stock culture, no increase in piliation was observed by electron microscopy after RBC passage. Despite becoming more strongly $\mathrm{HA}+$, strain $\mathrm{C} 186$ showed only a moderate increase in its number of pili (10-20 pili on some but not all bacteria). Non-selective in-vitro subculturing of the selected HA + subpopulations of bacteria resulted in loss of HA, a return to degrees of adherence comparable to those of the SC parent strain and a reversion to non-piliated forms by all of the CSF and blood strains. Strains C54 and $\mathrm{C} 186$ also reverted in all respects to the condition of their parents.

\section{Discussion}

An improved understanding of $H$. influenzae b adherence to EC is important in increasing our knowledge of $H$. influenzae $b$ pathogenesis. In this report, a sensitive assay for detecting $H$. influenzae b adherence is described. Sensitivity was achieved by intrinsically labelling the bacteria, by minimizing non-specific attachment of the bacteria to reaction vessel walls, by reducing the background radio-activity which resulted from release of ${ }^{3} \mathrm{H}$-labelled capsular polysaccharide into the reaction buffer, and by complete disintegration of the final EC-bacteria pellet. The degree of $H$. influenzae $\mathrm{b}$ adherence was significantly influenced by incubation time, temperature and bacteria:EC ratio. Bacteria adhered in greater numbers to pharyngeal cells than to buccal cells when the counts were corrected for cell surface area (Salit and Morton, 1981). The optimal conditions for $H$. influenzae b adherence to EC were similar to those previously described for other bacterial species (Svanborg-Eden et al., 1977; Andersson et al., 1981).

Studies of Neisseria meningitidis (Craven et al., 1980; Stephens and McGee, 1981) and Streptococcus pneumoniae (Selinger and Reed, 1979; Andersson et al., 1981) have shown that capsulated organisms adhere in smaller numbers than non-capsulated organisms. This general phenomenon of capsulation impeding adherence has been ascribed to electrostatic repulsion from the interaction of the negatively charged EC surface and the negatively charged capsule (Heckels et al., 1976) or to the blocking or covering of attachment sites on the bacterial outer membrane by capsular material or 
both. Two observations presented in this report support this concept: (1) the capsule-deficient mutant strain of a type-b capsulated strain (Eag) adhered in significantly greater numbers to EC than did its fully capsulated parent strain, and (2), as a group, the SC capsulated strains of $H$. influenzae adhered in significantly smaller numbers than did the non-capsulated strains.

Meningococci that are both capsulated and piliated demonstrate a marked affinity for EC (Craven et al., 1980). It is thought that the pili may bridge the opposing electrostatic forces between the capsular polysaccharide and the EC surface. The type-b capsule of $H$. influenzae, being a polymer of ribosyl ribitol phosphate, confers a high negative charge on the bacteria. The findings of this report suggest that $H$. influenzae b strains which have undergone non-selective serial in-vitro subculturing maintain capsulation while piliation is generally lost. It seems likely that the small amount of EC adherence that is achieved by such strains is due to the presence of a few piliated organisms among the many non-piliated daughter cells. Progeny of this small subpopulation of piliated organisms can be generated by selective in-vitro passage of RBC- or EC-adherent bacteria (Pichichero et al., 1982). Such progeny demonstrate pili on most daughter cells and are highly EC-adherent. Stable piliation of $H$. influenzae b appears difficult to maintain in most cases; strain C54 is an exception. Non-selective in-vitro passage of a piliated population typically results in reversion to the non-piliated state, with a corresponding decrease in EC adherence.

The results of this study suggest that the presence of pili on $H$. influenzae b correlates quantitatively with adherence of the bacteria to EC. Identification of a pilus receptor on human $\mathrm{EC}$, and experiments demonstrating blocking of pilus interaction with EC by purified pilus subunit protein, specific lectins or anti-pilus antibody, would lend further support to this possibility. Direct confirmation of the importance of $H$. influenzae b pili in EC adherence will require identification of a genetic mutant pair where the only variant is the presence of pili.

Pilus-mediated adherence of several other bacterial species to EC or to RBCs has been shown to be an attribute of virulent strains (Ofek and Beachey, 1980). Mucosal antibody directed against pili diminishes bacterial adherence and may prevent infection (Fubara and Freter, 1973; Cantey, 1978). Further study of the role of $H$. influenzae $\mathrm{b}$ pili in pathogenesis may show that pilus-mediated bacterial adherence at the mucosal surface can be prevented by secretory antipilus antibodies. This would indicate a new strategy for prevention of $H$. influenzae b disease by vaccination.

The skilful technical assistance of Joyce Colaiace, electron microscopy by Edward Connor, helpful discussion and review of the manuscript by Porter Anderson, Richard Insel and Marilyn Loeb, and secretarial support by Pam Iadarola are gratefully acknowledged.

This work was presented in part at the Society for Pediatric Research annual meeting in May, 1982 at Washington, DC and was supported by National Institute of Health Training Grant AI 07169 and U.S. Public Service Contract AI 72523.

\section{REFERENCES}

Andersson B, Eriksson B, Falsen E, Fogh A, Hanson L A, Nylen O, Peterson H, Svanborg Eden C 1981 Adhesion of Streptococcus pneumoniae to human pharyngeal epithelial cells in vitro: Differences in adhesive capacity among strains isolated from subjects with otitis media, septicemia, or meningitis or from healthy carriers. Infection and Immunity 32:311-317. 
Anderson P 1978 Intrinsic tritium labeling of the capsular polysaccharide antigen of Haemophilus influenzae type b. Journal of Immunology 120:866-870.

Anderson P, Johnston R B, Smith D H 1972 Human serum activities against Hemophilus influenzae, type $\mathrm{b}$. Journal of Clinical Investigation 51:31-38.

Cantey J R 1978 Prevention of bacterial infections of mucosal surfaces by immune secretory IgA. In: McGhee J R, Mestecky J, Babb J L (eds) Secretory immunity and infection (Advances in Experimental Medicine and Biology, 107) Plenum Press, New York pp 461-470.

Craven D E, Peppler M S, Frasch C E, Mocca L F, McGrath P P, Washington G 1980 Adherence of isolates of Neisseria meningitidis from patients and carriers to human buccal epithelial cells. Journal of Infectious Diseases 142:556-568.

Fubara E S, Freter R 1973 Protection against enteric bacterial infection by secretory IgA antibodies. Journal of Immunology 111:395-403.

Guerina N G, Langermann S, Clegg H W, Kessler T W, Goldmann D A, Gilsdorf J R 1982 Adherence of piliated Haemophilus influenzae type b to human oropharyngeal cells. Journal of Infectious Diseases 146:564.

Heckels J E, Blackett B, Everson J S, Ward M E 1976 The influence of surface charge on the attachment of Neisseria gonorrhoeae to human cells. Journal of General Microbiology 96:359-364.

Lampe R M, Mason E O, Kaplan S L, Umstead C L, Yow M D, Feigin R D 1982 Adherence of Haemophilus influenzae to buccal epithelial cells. Infection and Immunity 35:166-172.

Lewis J M, Dajani A S 1980 Adherence of Haemophilus influenzae to human epithelial cells. Abstracts of the Annual Meeting of the American Study for Microbiology, p 26.

Loeb M R, Smith D H 1980 Outer membrane protein composition in disease isolates of Haemophilus influenzae: Pathogenic and epidemiological implications. Infection and Immunity 30:709-717.

Moxon E R, Smith A L, Averill D R, Smith D H 1974 Haemophilus influenzae meningitis in infant rats after intranasal inoculation. Journal of Infectious Diseases 129:154-162.

Ofek I, Beachey E H 1980 General concepts and principles of bacterial adherence in animals and man. In: Beachey E H (ed) Bacterial adherence. Chapman and Hall, London pp 1-29.

Pichichero M E, Loeb M, Anderson P, Smith D H 1982 Do pili play a role in pathogenicity of Haemophilus influenzae type b? Lancet:2:960-962.

Salit I E, Morton G 1981 Adherence of Neisseria meningitidis to human epithelial cells. Infection and Immunity 31:430-435.

Selinger D S, Reed W P 1979 Pneumococcal adherence to human epithelial cells. Infection and Immunity 23:545-548.

Stephens D S, McGee Z A 1981 Attachment of Neisseria meningitidis to human mucosal surfaces: Influence of pili and type of receptor cell. Journal of Infectious Diseases 143:525-532.

Svanborg Eden C, Eriksson B, Hanson L A 1977 Adhesion of Escherichia coli to human uroepithelial cells in vitro. Infection and Immunity 18:767-774.

Weller P F, Smith A L, Smith D H, Anderson P 1978 Role of immunity in the clearance of bacteremia due to Haemophilus influenzae. Journal of Infectious Diseases 138:427-436. 